\begin{tabular}{c|l|l|l}
$\begin{array}{c}\text { Case Reports in } \\
\text { Oncology }\end{array}$ & $\begin{array}{l}\text { Case Rep Oncol 2010;3:349-353 } \\
\text { DOI: 10.1159/000321367 }\end{array}$ & $\begin{array}{l}\text { Published online: } \\
\text { October 4, 2010 }\end{array}$ & $\begin{array}{l}\text { O 2010 S. Karger AG, Basel } \\
\text { ISSN 1662-6575 } \\
\text { www.karger.com/cro }\end{array}$ \\
\hline
\end{tabular}

This is an Open Access article licensed under the terms of the Creative Commons AttributionNonCommercial-NoDerivs 3.0 License (www.karger.com/OA-license), applicable to the online version of the article only. Distribution for non-commercial purposes only.

\title{
Auricular Oedema and Dyshidrotic Eczema in a Patient with Acute Myeloid Leukaemia Treated with Cytarabine
}

\author{
K. Brandt ${ }^{\mathrm{a}} \quad$ K. Schäkel ${ }^{\mathrm{b}} \quad$ F. Stölzel ${ }^{\mathrm{a}} \quad$ J. Janschek ${ }^{\mathrm{a}}$ \\ G. Ehninger ${ }^{\mathrm{a}} \quad$ M. Schaich ${ }^{\mathrm{a}}$ \\ aUniversity Hospital Carl Gustav Carus, Department of Internal Medicine I,

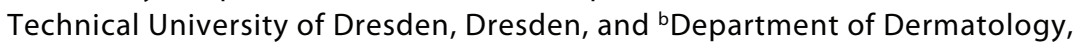 \\ Heidelberg University Hospital, Heidelberg, Germany
}

\section{Key Words}

Cutaneous toxicity - Cytarabine - Auricular oedema - Palmar dyshidrotic eczema - Acute myeloid leukaemia

\begin{abstract}
Cytarabine is an effective drug in the treatment of haematological malignancies. The therapy is associated with various complications. Frequencies of dermatological sideeffects range from $2-72 \%$ and occur most commonly after high-dose regimens. Although most cutaneous reactions are mild and resolve spontaneously within several days, they may result in an increased risk of infection and alterations in comfort. In some cases, severe life-threatening reactions have been reported. Here we describe the case of a patient with acute myeloid leukaemia, who developed severe exceptional skin toxicity in terms of auricular oedema and palmar dyshidrotic eczema after the application of lowdose cytarabine. Re-administration of the drug resulted in reduced skin toxicity during further cycles of chemotherapy. Negative epicutaneous patch-testing supported the existence of cytarabine-provoked toxicity.
\end{abstract}

\section{Introduction}

Cytarabine is a pyrimidine antagonist used in the treatment of haematological malignancies. In combination with other chemotherapeutic agents, it is indicated amongst others for remission induction in acute myeloid leukaemia (AML). High-dose cytarabine is applied in consolidation chemotherapy. Nevertheless, cytarabine is known to provoke various adverse effects, including bone marrow depression, fever, nausea, vomiting, keratoconjunctivitis, liver-function abnormalities, pulmonary, gastrointestinal and neurological complications and skin reactions. Especially in high-dose regimens, 
dermatological side-effects of cytarabine therapy occur more prevalently. The frequencies of toxic skin events range from $2-72 \%$ in the literature [1]. Here we report the case of a patient with AML, who developed exceptional skin toxicity in terms of auricular oedema and palmar dyshidrotic eczema.

\section{Case Report}

A 38-year-old woman was admitted to our hospital because of recurrent syncopes, haematomas and hypermenorrhea for further investigations. At presentation, full blood count demonstrated a leukocytosis of $50.6 \times 10^{9} / \mathrm{l}$, anaemia of $7.41 \mathrm{~g} / \mathrm{dl}(4.6 \mathrm{mM})$ and a platelet count of $17 \times 10^{9} / 1$. Seventy-one percent blast cells were noted on the peripheral blood smear. Bone marrow examination established the diagnosis of AML with maturation according to the WHO classification and aberrant expression of CD7. Cytogenetic analysis revealed mosaicism for trisomy $19(46, \mathrm{XX} / 47, \mathrm{XX}+19)$. Molecular biology remained negative for mutations in the FLT3 and NPM1 genes. The patient was included into the prospective multicentre trial AML2003 of the Study Alliance Leukemia (SAL). Induction chemotherapy consisted of daunorubicin $60 \mathrm{mg} / \mathrm{m}^{2}$ (days 3-5) and cytarabine $100 \mathrm{mg} / \mathrm{m}^{2}$ (days 1-7). In addition to chemotherapy, the patient received supportive medication consisting of levofloxacin $500 \mathrm{mg}$ per day (q.d.) on days -3 to 1 , posaconazole $600 \mathrm{mg}$ q.d. on days -3 to 6 , acyclovir $600 \mathrm{mg}$ q.d. on days -3 to 6 , allopurinol $300 \mathrm{mg}$ q.d. on days -3 to 6 , heparin 10,000 IU q.d. on days 5-6 and esomeprazole $20 \mathrm{mg}$ q.d. on days -3 to 6 . On day 1 of the induction therapy, the patient developed fever and was set on piperacillin-tazobactam 13.5 g q.d. on days 1-6. Due to hypermenorrhea, methylergometrine $0.75 \mathrm{mg}$ q.d. was given on days -2 to 6 . Before starting chemotherapy, hydroxycarbamide $3 \mathrm{~g}$ q.d. was given on days -3 to -1 because of hyperleukocytosis. On day 6 of the first induction therapy, the patient developed a doughy, painful erythematous swelling of both ears (fig. 1a), haemorrhagic papulovesicles on both hands and an erythematous patch on the thenar eminence accompanied by pyrexia (fig. 1b). The clinical picture of both ears was evocative of the immune-mediated relapsing polychondritis (polychondritis recidivans et atrophicans).

However, first induction chemotherapy was completed. Because of a potential allergic cause of the described reactions, the supportive medication mentioned above was stopped on day 6. Due to increasing body temperature and leukopenia $\left(1.66 \times 10^{9} / \mathrm{l}\right)$ piperacilline-tazobactam was replaced by the antibiotic combination of vancomycin and meropenem on day 7. Dermatological manifestations were treated with topical and oral administration of glucocorticoids and regressed within 7 days (fig. 2a, b).

For response evaluation, the patient underwent bone marrow examination on day 14 after the start of the first induction therapy. Morphological and immunophenotyping analyses showed a good response with $4 \%$ blast cells in the hypocellular bone marrow. According to the study protocol, second induction therapy was initialised on day 22. Dosages and chronological administration of the chemotherapeutic drugs daunorubicin and cytarabine were consistent with the first induction therapy. Between the chemotherapy cycles, antiviral, antimycotic and antibiotic therapy with acyclovir, posaconazole and levofloxacin was given again and did not provoke any dermatological side-effects. Prophylactic medication of heparin and esomeprazole was also started again. On the first day of the second induction therapy, pyrexia recurred, probably in the context of an adverse event of cytarabine. Even so, antibiotic therapy with levofloxacin was again replaced by piperacillin-tazobactam on day 2 of the second induction therapy because of persistent neutropenia. On day 3 , the patient developed a maculopapular exanthema of the neck, lower legs and thenar eminence of the left hand as well as auricular erythematous swelling on both sides. However, compared to the initial dermatological manifestation during the first induction chemotherapy, the degree of skin toxicity was markedly reduced. Therapy consisted of topical and oral glucocorticoids, again. Efflorescences dissolved within 4 days.

Based on standard-risk AML, the patient underwent three consolidation chemotherapy cycles with high-dose cytarabine $\left(2 \times 3 \mathrm{~g} / \mathrm{m}^{2}\right.$ on days 1,3 and 5$)$, consistent with the study protocol. A HLAmatched sibling donor for allogeneic hematopoietic stem cell transplantation was not available. A pronounced reduction of dermatological toxicity appeared on day 7 of the first and second consolidation chemotherapy, demonstrating as maculopapular exanthema of the lower legs. No dermatological toxicity was observed after application of the third consolidation therapy. Supplementary medication did not differ from treatment during both induction regimens. 


\begin{tabular}{r|l|l|l}
$\begin{array}{c}\text { Case Reports in } \\
\text { Oncology }\end{array}$ & $\begin{array}{l}\text { Case Rep Oncol 2010;3:349-353 } \\
\text { DOI: 10.1159/000321367 }\end{array}$ & $\begin{array}{l}\text { Published online: } \\
\text { October 4, 2010 }\end{array}$ & $\begin{array}{l}\text { O 2010 S. Karger AG, Basel } \\
\text { ISSN 1662-6575 } \\
\text { www.karger.com/cro }\end{array}$ \\
\hline
\end{tabular}

Epicutaneous patch-testing with cytarabine was performed before starting the third consolidation chemotherapy. 24, 48 and $72 \mathrm{~h}$ after administration of the drug, no cutaneous reaction could be observed, which argues against the possibility of cytarabine-specific and T-cell mediated type IV reactions in this patient.

\section{Discussion}

As cyrarabine is considered one of the most important drugs for the treatment of AML, it is important to be aware of complications that may occur in patients treated with this drug. There are several reports in the literature that mention cytarabine as a cause of severe dermatological toxicity $[1,2]$. Nevertheless, mild skin complications preponderate. Most of the cutaneous reactions begin few days after the initiation of chemotherapy and resolve within several days of their appearance. Known manifestations of skin toxicity can be multifaceted, ranging from palmar-plantar erythema and morbilliform eruptions on the trunk to erythematous urticarial plaques, bullous erythema and painfull swelling. Two cases of toxic epidermal necrolysis had been described after the use of high-dose cytarabine $[2,3]$. Skin changes are supposed to be dose-related and occur more frequently with high-dose regimens [1]. Regarding intensity of dermatological adverse reactions after repetitive administration of cytarabine, gradual amelioration of symptoms during further cycles of chemotherapy is not uncommon $[1,4,5]$. The pathogenesis of cytarabine-induced dermatological toxicity still remains unclear.

Here, we report the unusual case of distinctive auricular swelling, accompanied by palmar papulovesicles as a variant of cytarabine-induced toxicity. Skin manifestation occurred several days after the administration of cytarabine and showed diminished intensity in the course of drug re-administration. Although skin toxicity induced by lowdose cytarabine is reported to be rare, the patient developed severe dermatological complications after the first cycle. Negative epicutaneous patch-testing was used to rule out specific T-cell mediated responses and supports the existence of cytarabine-provoked toxicity. Finally, a connection between supportive medication and cutaneous reaction seems improbable. For the most part, co-medication was given non-intermittent during the cycles. However, skin toxicity recurred several times. Moreover, there is no evident chronological relationship between dermatological manifestation and supportive drug administration.

\section{Disclosure Statement}

The authors certify that there is no actual or potential conflict of interest in relation to this article. 


\begin{tabular}{c|l|l|l}
$\begin{array}{c}\text { Case Reports in } \\
\text { Oncology }\end{array}$ & $\begin{array}{l}\text { Case Rep Oncol 2010;3:349-353 } \\
\text { DOI: 10.1159/000321367 }\end{array}$ & $\begin{array}{l}\text { Published online: } \\
\text { October 4, 2010 }\end{array}$ & $\begin{array}{l}\text { O 2010 S. Karger AG, Basel } \\
\text { ISSN 1662-6575 } \\
\text { www.karger.com/cro }\end{array}$ \\
\hline
\end{tabular}
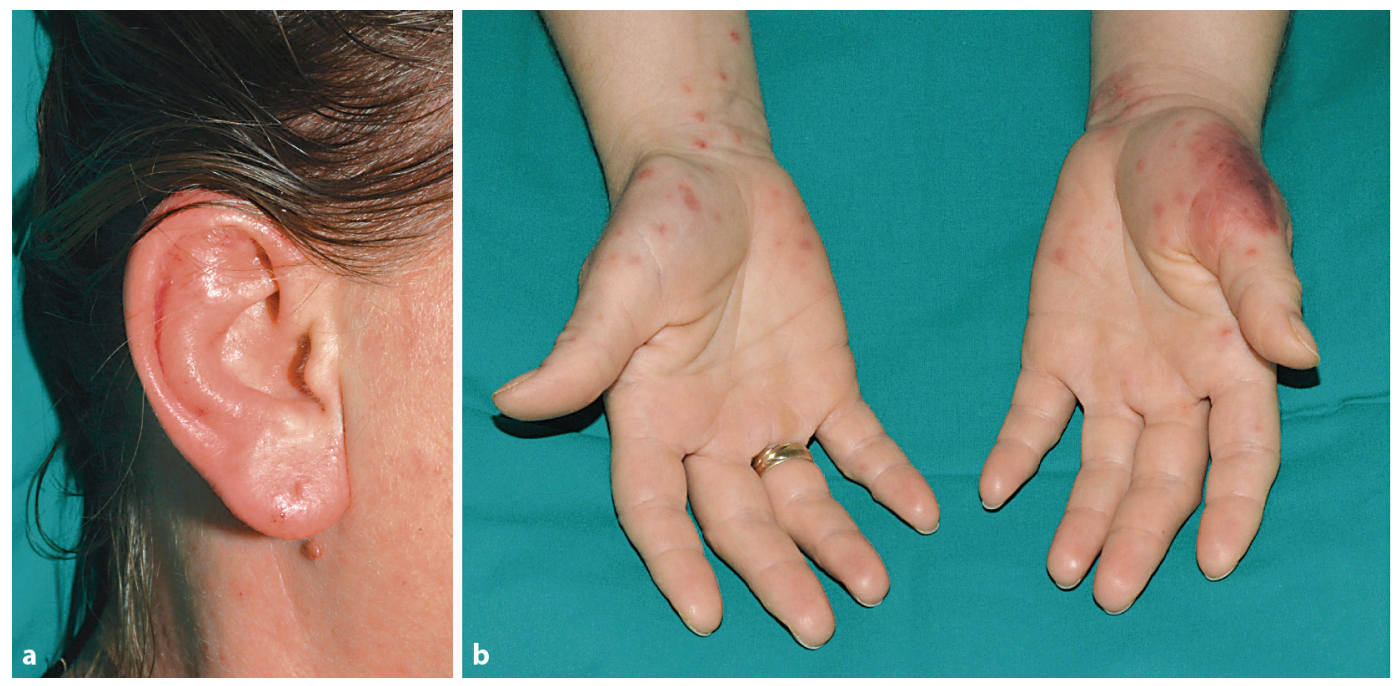

Fig. 1. a Erythematous, doughy swelling of both ears on day 6 of the first induction therapy (right side). b Haemorrhagic papulovesicles on both hands and erythematous patch on the thenar eminence on day 6 of the first induction therapy.
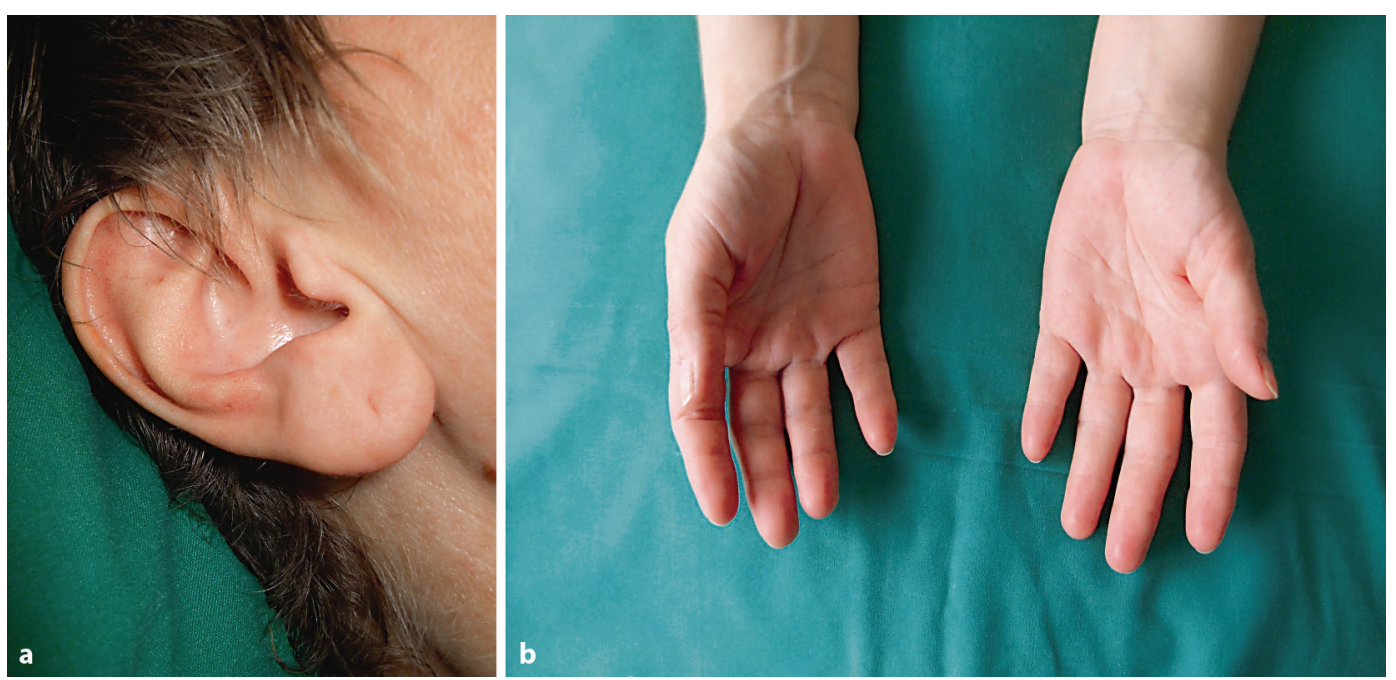

Fig. 2. a, b Complete restitution of cutaneous toxicities 7 days after their appearance. 


\section{References}

1 Cetkovská P, Pizinger K, Cetkovský P: High-dose cytosine arabinoside-induced cutaneous reactions. J Eur Acad Dermatol Venereol 2002;16:481-485.

-2 Ozkan A, Apak H, Celkan T, Yüksel L, Yildiz I: Toxic epidermal necrolysis after the use of high-dose cytosine arabinoside. Pediatr Dermatol 2001;18:38-40.

-3 Figueiredo MS, Yamamoto M, Kerbauy J: Toxic epidermal necrolysis after the use of intermediate dose of cytosine arabinoside. Rev Assoc Med Bras 1998;44:53-55.

-4 Baack BR, Burgdorf WH: Chemotherapy-induced acral erythema. J Am Acad Dermatol 1991;24:457-461.

5 Blanca M, Torres MJ, Girón M, Corzo JL, Martínez-Valverde A: Successful administration of cytarabine after a previous anaphylactic reaction. Allergy 1997;52:1009-1011. 